\title{
Mia Hall's Decision-Making in If I Stay by Gayle Forman Based on Freudian Psychoanalysis Theory
}

\author{
Cindy Leonita, Yohanes Kurniawan, Eka Fadillah \\ ${ }^{1,2,3}$ English Department of Widya Kartika University, Surabaya \\ "Corresponding Author: cleonita7@gmail.com
}

\begin{abstract}
This study aims at investigating a decision-making process based on Freudian Psychoanalytic theory in Gayle Forman's If I Stay. This study specifically focuses on the main character, Mia Hall. Based on Freud's, all human behaviour, including decision-making, is influenced by the interaction of three structures of personality: Id, Ego, and Superego. This study discussed the interrelation of those structures in affecting Mia's decision-making process. Furthermore, this study also searched for the prominent domination explicated in Mia's final decision. The writers applied Freudian Psychoanalysis to reveal the main focus of this study. The compelling utterances and narrations from the novel are considered the primary source of data. Then, the data are classified into Id, Ego, and Superego before looking for the interrelation and dominant structure. Besides Psychoanalytic, this study also applied character and characterization theory to help the writers analyse the utterances and behaviour of Mia. The result reveals that, though the Id, Ego, and Superego have their desire, these three structures can balance each other and eventually lead Mia to a decision. It is crucial to learn and investigate the dynamic of the decision-making process encountered by a human.
\end{abstract}

Keywords: Psychoanalytic, Decision-making, Id, Ego, Superego

\section{INTRODUCTION}

Inevitably, humans are always confronted with choices in their daily life. Such choices lead them to have the right decision-making as a necessary skill from a psychological perspective. Decision-making is one of the necessary skills a person should have in their life since every decision shapes experiences and sometimes affects others. Instead of following the guts of what we want, it is better to consider other things such as the value, consequences, and many more to find the best answer. Shahsavarani and Esfandiar (2015) argued that decision-making is related to problem-solving, ending when the decision-maker reaches a satisfying solution. The process can be rational or emotional, logical or illogical, and explicit or implicit, depending on how the decision-maker processes the choices through the consequences and level of interpretation. Most of our decisions are based on our behaviours and actions, shaped and influenced by culture, perceptions, belief systems, knowledge, insight into the decision-maker, including personality. A combination of personality traits represents a key factor in decisionmaking that could affect decisions about actions (McTernan, Love, \& Rettinger, 2013).

The discussion in regard to human behaviour psychologically is anchored in a big theory called Psychoanalysis. According to Hossain (2017), Psychoanalysis is regarded as a theory of personality organization and dynamics to show human behaviour that occurs due to unconscious and consciousness' interactions. Today's fictional literature begins or contains human phenomenon and behaviour, including the decision-making process as the main plot development. One of them is If I Stay by Gayle Forman published in 2014. Through their study, 
Journal of Literature, Linguistics, and Language Teaching

Volume 2 (2) 2021

ISSN:2746-8968

https://journal.unesa.ac.id/index.php/nld/index

Christine and Widyastuti (2017) concluded that the unconscious mind influenced and motivated someone's decision-making process through the impact of memories that have been recorded throughout their life. Additionally, Mia Hall's decision is influenced by her characteristics formed unconsciously as she grew up. The result is in accordance with Jung's theory that consciousness (ego) is not the core of personality that plays only a minor role in analytical psychology study.

Sigmund Freud, through his study, believed that behaviour and personality derived from the constant and unique interactions between the three levels of the human mind, which are conscious, unconscious, and preconscious (Schultz \& Sydney, 2017). Based on Freud, consciousness is only a thin slice of the human mind. Meanwhile, unconsciousness takes the largest part of the human mind (Schultz \& Sydney, 2017: 45). However, this does not mean that unconsciousness ultimately influences the human mind. The writers believed that there should be an interaction between conscious and unconsciousness related to every human's behaviour, including decision-making. Regarding Freud's theory, there must be an interaction between the unconscious and consciousness to produce a good and healthy behaviour or personality.

In Mia Hall's situation, although she is physically unconscious, there must be an interaction between these structures in proceeding with the choices. There might be several acts Mia experienced that affected her consciously and unconsciously. Moreover, there must be balancing desires between these two structures, as Freud explained in his theory.

In this study, the writers seek Mia Hall's decision-making process through her personality based on the interrelation between the Id, Ego, and Superego based on Freudian's Psychoanalytic theory. The writers believed that Mia's decision was not only influenced by her unconsciousness (Id), as the previous study claimed. However, consciousness (Ego and Superego) also takes part in this decision-making process. Likewise, the writers also depicted the most dominant structure related to Mia's final decision to wrap up this study.

\section{The Id}

In line with Freud, the Id is the source of all psychic power, and it is the number one thing of personality. It's miles egocentric, pride-looking for, primitive, amoral, insistent, and rash. It consists of instinctive and primitive behaviours that respond at once to fundamental urges, needs, and desires (Cherry, 2020). The Id remains the same in its function throughout a person's life and does not change with time or experience. The Id operates on the pleasure principle, which is that the idea should be satisfied immediately, regardless of the consequences (Schultz \& Sydney, 2017: 45). The Id engages in the process of thinking, which has no comprehension of objective reality and is selfish.

Immediately fulfilling Id's needs is not always realistic and right. Freud defined that the Id tries to clear up the tension created by the pleasure principle through primary-process thinking, which involves forming a mental image of the desired object to satisfy the need. Shortly, most of the behaviour derived from Id has no awareness of reality.

\section{Ego}

Opposite the id, the Ego evolved to mediate between the unrealistic id and the external objective world. The Ego is part of the id that has been modified by the direct influence of the surroundings. The Ego is also commonly compromising or postponing satisfaction to avoid bad outcomes in society. Ego commonly engages in secondary methods and is centred on problem-fixing. Ego tends to locate the amicable solution or choice and try to control id's impulses (McLeod, 2019). 
Journal of Literature, Linguistics, and Language Teaching

Volume 2 (2) 2021

ISSN:2746-8968

https://journal.unesa.ac.id/index.php/nld/index

\section{Superego}

The Superego develops last and exists based on morals and judgements about right and wrong. Superego is strong and has a large part in the subconscious that humans acquire in adolescence. It is about the idea of right and wrong concerned with social rules and morals, similar to what many people call their "conscience" or their "moral compass." It functions as persuading the Ego to show to moralistic as opposed to absolutely sensible ones and seeking perfection (Schultz \& Sydney, 2017: 47). Even though Superego and Ego are likely result in the identical choice or behaviour, the Superego's purpose is always based on ethical values. In evaluation, the Ego's purpose is primarily based on what consequences of an action or other people assumptions (McLeod, 2019).

\section{RESEARCH METHOD}

We utilized Freudian Psychoanalysis to investigate any utterances that explicated the main characters' decision-making process as the main focus of this study. According to Hossain (2017), Psychoanalysis is a theory of personality organisation and personality dynamics. Psychoanalysis aims to show behaviour that occurs due to unconscious and consciousness' interactions. This theory can find the hidden meaning of a literary work that may bring out a different perspective. This method is applied by providing the data from the utterances depicted in the research instrument, which is the novel itself. In collecting the data, the writers first reviewed and synthesized the content of the novel to figure out and locate any information referring to the main discussion to reveal. We then listed the utterances and narrations in regard to Mia's behaviour depicted in the novel covering Id, Ego, and Superego. Furthermore, we categorized the utterances based on each of the structures characterized in the psychoanalysis above mentioned. We eventually described and explicated the interrelation of the three categorical structures. Finally, we presented the dominant structure based on Mia's final decision-making.

\section{FINDINGS AND DISCUSSION}

If I Stay is a story about Mia Hall's outer-body experience after a car accident that happened to her family on their way to their grandparents' house. Their car was fully damaged (p. 15) and made her father and mother die right away after the accident. Her brother was critical but did not make it to the end of the story. The rest of the story then follows her decision-making process of whether to stay or leave the world to be reunited with her parents and little brother. In this chapter, the writers analysed Mia's personality based on Freud's theory which affected or related to her decision-making process.

\section{The Id}

Mia's Id is depicted through her monologues and actions that show her emotions. In the first situation, Mia faces tremendous confusion between life and death. Mia's confusion is exacerbated by the fact that she has to live without her parents. Therefore, at the same time, she does not want her brother, Teddy, to be left alone if he survived (p. 88). But when Teddy did not survive, her confusion turned into despair. Afterward, she realised that she was hopeless about staying (p. 164). She does not find any more reason to stay in the world because she does not have her family around. As someone close to her family, she would 
Journal of Literature, Linguistics, and Language Teaching

Volume 2 (2) 2021

ISSN:2746-8968

https://journal.unesa.ac.id/index.php/nld/index

not meet her parents and little brother if she stays is a bitter reality that is hard for her to live (p. 164). Living is hard for her (p. 175). In this situation, Mia's despair to stay is confirmed.

Based on Freud (1939), Id's desire is seen at the beginning of her outer-body experience. Mia loves her family, and she must have her family around, especially her parents. She is frustrated and devastated after what happened to her family because, for Mia, the family has become a significant part of her life since birth, and as a child, it is hard to live without them around. This need has been there since Mia was a little girl. She knew how much her parents loved her and her little brother because her parents never called her and Teddy accidents, surprises, or other callings. Moreover, Mia is in despair because she needed a support system in her life, and that was given by her parents.

Mia Hall was a family-centred person because she always focused and loved her family first (Christine \& Widyastuti, p. 52). It is unconsciously built in her personality. Mia's love for her family, especially her parents, is understandable since they are close, making the family connected. Through all the flashbacks stories in the novel, a family is a place where Mia can always come back. Therefore, Mia could not live in a world where her family was not around her, where her parents were not around. Then because of these matters, her Id strongly made her desire to leave the world because all of her family members died, and she did not find any solution to fulfill this desire if she chose to stay. Her unconsciousness works upon this desire since she did not realize the consequences and just decided based on her urges.

\section{Ego}

The writers assume that Mia's Ego's impulse work when she saw her surroundings while she was in outer-body experience. Through this experience, she was able to hear and see everything that helped her to realize reality. Through her monologue on page 217, she stated that she wanted to remember all her memories with Kim. This shows that Mia's difficulty in leaving the world. However, Mia knows that she still has hope in her life through the love and affection given by the people she mentions, such as her grandparents and Kim. Besides them, Mia's boyfriend, Adam, also another consideration for Mia to make up her mind to leave the world because remembering Adam would be like losing him all over again, and she was not sure if she could handle it (p. 217). Her love towards Adam is strong enough to make Mia changes her mind right away. She knows that she has to leave everything in the world as the consequences of leaving the world, including Adam, and it will be the hardest thing for her.

Mia's dream to become a cellist through Juilliard University is also a trigger towards her Ego. Before the accident happened, she was excited to apply to Juilliard despite having a long-distance relationship with Adam if she was accepted to Juilliard. There was a time when she was not sure whether she could spend the following Christmas and New Year with Adam because if Mia gets accepted to Juilliard, it might be hard for her to come home though she would if she could (p. 207). She told her mom about this, and after the conversation with Adam, she realized that whatever happens, she will not turn down Juilliard (p. 212).

Mia's dream to Juilliard is not just a dream. Cello is also a part of her life that she treasures a lot. Even Adam, one of the most influential people to her, could not stop her from canceling this dream. That is why, in another moment, when Adam said he wanted Mia to stay and is ready to do anything if she wakes up, Mia's Ego emerges. She feels the 
supports and love that was given to her. She is given hope to stay because she also has a future in Juilliard that awaits her if she wakes up (p. 233).

In many of Mia's monologues, the writers conclude that Mia's love for Adam is strong. Mia almost chose to leave the world after her Gramps told her that it was okay to go and stop fighting (p. 181). Hence, in her monologue, she gave up her intention to meet Adam because Mia knew she might change her mind if she met him. Her love for Adam is too strong, and it is even able to influence her mind. In the monologue above, when Mia decided to overcome her coma to continue her life, she tried to hold and felt Adam's hand because she believed that was the only way to survive the battle.

\section{Superego}

As Freud describes in his theory, the Superego is related to moral value. An individual obtains and learns moral value through parents and society. In Mia's case, her Gramps, Adam, and Kim influenced Mia's Superego. Gramps, who greatly hoped Mia to stay simultaneously, also stated that He would appreciate whatever the choice (p. 181). Kim also said that she wanted Mia to stay because losing her would be the worst thing for Kim (p. 217). Finally, Adam, Mia's lovely boyfriend, said the same point that he wanted Mia to stay. Even Adam was willing to do everything to support Mia (p. 230-231). The EgoIdeal, which is Superego's component, is reassured that she has to stay and Mia should fight the battle because she realized that she had them as the reason to stay, as her support system.

It is human nature to survive in this world. This nature has been understood by all organisms in the world, including animals. Therefore, through people who persuade Mia to stay, she is reminded that humans should survive. According to Hodge (2017), the moral of nature is to survive. Humans do not make this moral, but they are to be discovered by humans. It means that life itself is not an option, but humans should strive for life though it may cost energy. Relating to Mia's condition, what Mia's Gramps, Kim, and Adam said was a reminder for Mia that she had to stay because we have to fight for our life as a being, especially humans. If Mia decides to leave, she may feel guilty as she said she wanted to remember them (p. 217).

\section{The Interrelation between the Id, Ego, and Superego}

Before further explanation, the writers provided the figure below to make it easier for the readers to picture the interrelation: 


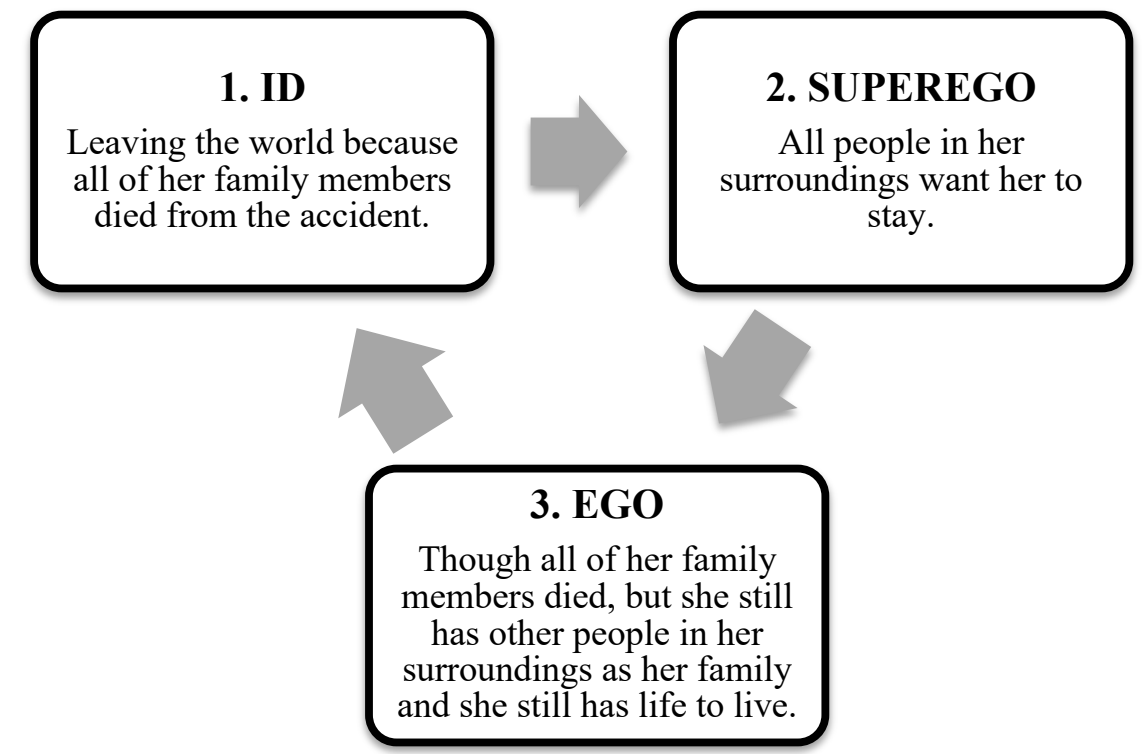

Figure 1. The Interaction Figures of Id, Ego, and Superego.

The Id, as the primary urge, occurs at the beginning of the story. This desire occurs because of the instinct of a child who was raised in a lovely and supportive family. Abraham Maslow (1943), in his worldwide known theory of basic human needs, stated that people seek to overcome loneliness and alienation by giving and receiving love, affection, and the sense of belongingness to people around them (McLeod, 2020).

In Mia's case, this urge is seen from the first thing she did after her soul woke up was find her family. Mia became desperate when she found out that her Mom and Dad died right after the accident, and she almost decided to leave the world. Though this desire was postponed because of her little brother's condition, it strengthened when Teddy died. Teddy was the last hope and reason for Mia to stay, and when Teddy died, all she was thinking about was leaving the world because she did not belong there anymore (p. 164). This thought of hers happened in her unconscious mind. All she was thinking about was the way to avoid the pain caused by the unfulfilled desire, which is the existence of her parents and brother.

Based on Id's desire, Superego occurs through people in her surroundings, such as her grandparents, Adam and Kim, who want Mia to stay. It postponed Mia's decision that she was about to choose before. Though Mia heavily wanted to leave because of her parents and little brother, she received support from those she loved fighting and chose to stay with. Her loving traits towards those people who wait for her to wake up are emerging in this situation. Mia's Ego-Ideal learns that it is up to her, but she should stay because, according to her surroundings, she had to.

Both structures had their desire that affected Mia's decision-making process. According to Freud (1939), after the Id and Superego reveal their desire, it is time for the Ego to occur as the mediator of unrealistic desire (Id) and the external world desires (Superego). The writers assume that Mia's Ego is triggered more by the Superego. The main concern of Mia's difficulty in making a decision is the reality that her family member died. Therefore, thanks to Kim and Mia's grandparents, who convinced her that she would not be alone because she still has family, and because they also matter, Mia knows that she is still worth staying. These words comfort Mia and make her even harder to leave because 
Journal of Literature, Linguistics, and Language Teaching

Volume 2 (2) 2021

ISSN:2746-8968

https://journal.unesa.ac.id/index.php/nld/index

she loved them. Thanks to these people, Mia is shown another reality where she still has many reasons to choose to live.

Adam influences Mia differently. By saying that he wanted her to stay and would do anything that Mia wanted him to do, including supporting Mia to pursue her dream in Juilliard, Mia realized that cello had become a big part of her life. Her dream to become a cellist is strong enough to courage her decision. The writers assume that Mia's Ego works to see the reality that Mia's life is still worth fighting because of the cello. Her dream to go into Juilliard and be a cellist is honest enough to make her realize the reality of the life she has been waiting for a long time ago.

The writers realized that Mia's Ego was working before the Superego appeared. At first, Mia's Ego sees the death of all her family members as reality. It means that Mia has to live alone if she stayed. Because of the Id's urges and what the Ego sees, she is hopeless and about to leave the world. Nevertheless, at that time, the Superego was not working. After the Superego worked, the Ego has slowly changed how it sees reality and finally managed to make Mia decide her way.

In a nutshell, the Id, Ego, and Superego had their desire based on their impulses, and each of them influenced Mia's behaviour. As the mediator and the decision-maker from the three structures, the Ego could decide right away. However, as Freud explained, all three structures must work together to produce the best behaviour. The Ego tries to satisfy the Id's desire by adjusting and seeing the reality of Mia's surroundings, which include the Superego. Overall, the result of this interaction in Mia's decision-making process, which is to overcome her coma and stay, might be the best decision.

\section{The Dominant Superego}

In this discussion, the writers point out the dominant structure that affected Mia's final decision. The dominant structure that the writers pointed out in this discussion does not mean that the structure is completely dominating the decision. However, Freud explained, no structure can completely dominate each other. Each structure is not a separate entity because they constantly interact to influence an individual's personality and behaviour. Therefore, the dominating structure that the writers are referring to here is the structure that most influences Mia's final decision. At the end of the story, Mia decided to overcome her coma. In the writers' observation, the Superego affected Mia's final decision the most. The evidence to support the previous statement would be presented in this chapter.

Later on, Mia decided to stay and overcome her coma. The writers assume this decision is triggered by people in her surroundings who encourage her to stay. However, Mia's biggest concern to make a decision is because she lost all her beloved family members and has to live alone as an orphan without love and support from her family, especially her parents - this concern directing Id to leave the world. The Superego changes this concern and tells her to stay because she still has family such as her grandparents, Kim, Adam, Willow, and everyone who waits for her that will be there for her, especially her grandparents. Additionally, Adam, Mia's boyfriend, who encourages her and reminds Mia's dream to be a cellist, also triggered her Ego to think about how necessary cello is in Mia's life. The writers see this as another hope for Mia to stay.

To overcome her coma, she gathered all the love she got as the energy. Though she firmly understands it depended on her, her consideration towards those who waited for her to overcome her coma shows that she is looking for supporting reasons to choose. The people she mentioned in the last monologue should be those who matter in this decisionmaking process. At this point, she realizes that she has reasons to survive, namely because 
Journal of Literature, Linguistics, and Language Teaching

Volume 2 (2) 2021

ISSN:2746-8968

https://journal.unesa.ac.id/index.php/nld/index

of those people and also her dream that she anticipated. This matter inspires the Superego to dominate the Ego, which similarly sees the reality. To Mia, other people's existence is essential in her life because it supports and encourages her all this time. When it is related to the surrounding and social situation, then the Superego impulse is working.

According to Freud, the Ego must adequately moderate between the Id and Superego to produce a healthy and well-adjusted personality and behaviour. Mia's Ego, which is influenced by the Superego, is depicted through her monologue and actions before she finally decided to stay. The Ego, as the mediator, has to cope with the conflicting demands of the Id and Superego. Therefore, when Id pushes Mia to leave, the Ego tries to repress this desire by seeing that Mia still has many people she can call family. In many of her monologues, she is trying to picture her life without her parents and brother around her. Mia even imagined being called an orphan that seems frightening for her (p. 232). Nevertheless, at the same time, she also realized that there were still so many great unknowns that life might bring to her if she chose to stay (p. 233). That is when her Ego works.

Through this subchapter, the writers claim the role of consciousness in Mia's decision-making. As explained previously, Mia's Superego works as the dominant structure that affected Mia's decision to stay and overcome her coma. The writers see that her considerations to stay are influenced mainly by her surroundings, such as her grandparents, Kim and Adam. This consideration later becomes a part of Ego because it appears when she finally tries to see the reality that she has many reasons to live. As in Freud's iceberg analogy, Superego and Ego is part of consciousness in the human mind.

Related to the previous study that claimed Mia's decision-making was influenced by the unconscious mind, this claim is not complete. It may be true that unconscious affected decision-making through Mia's traits. The writer of the related study quoted Jonassen (2012) claimed that someone's unconscious mind can affect someone's decisionmaking which is based on the person's values depicted through emotions and choices. However, it does not mean that the unconscious works alone to do this. Another thing that Jonassen emphasized in his theory is the role of emotions, which is seen in Mia in almost all scenes of the story; the story she constructs about what happens if she chooses life or death on page 23 , and also how she figures out her situation. All these things would not happen without the role of consciousness that holds all memories, feelings, and thoughts, as Freud's said.

\section{CONCLUSION}

The finding of the study showed that the three structures of personality, the Id, Ego, and Superego, play significant roles through their desire and need interaction to result in a balanced decision. The interaction does not happen once, but it can happen many times depending on the personality or the value of the decision-maker. To finally reach the final interaction, there must be a dominating structure from all three. The domination here does not mean complete domination, but domination to balance every desire that each structure has. Those things have been proven in Mia Hall's decision-making process. Her Id, Ego, and Superego take part to help her finally reach out her final decision.

\section{ACKNOWLEDGEMENT}


Journal of Literature, Linguistics, and Language Teaching

Volume 2 (2) 2021

ISSN:2746-8968

https://journal.unesa.ac.id/index.php/nld/index

Many thanks to all parties who supported this research to be completed, especially to Yohanes Kurniawan, S.S., M.Pd. and Dr. Eka Fadilah S.S., M.Pd. who participated in conducting this research. Hopefully, this article can contribute to the teaching English.

\section{REFERENCES}

Abel, S. (2021, April 06). Interaction of the Id, Ego, and Superego - Personality Psychology. Doctor Steve Abel. Retrieved from https://www.doctorabel.us/personalitypsychology/interaction-of-the-id-ego-and-superego.html

Ackerman, C. E. (2020, December 09). Psychoanalysis: A Brief History of Freud's Psychoanalytic Theory [2019]. Positive Psychology. Retrieved from https://positivepsychology.com/psychoanalysis/

Adair J. (2007). Decision-making and Problem Solving Strategies ( $3^{\text {rd }}$ Ed.). Kogan Page.

Ahmed, M. T. \& Omotunde H. (2012). Theories and Strategies of Good Decision-making. International Journal of Scientific \& Technology Research 1(10), 51-54.

Arp, T. R., Greg J, Perrine L. (2015). Perrine's Literature: Structure, Sound and Sense. Wadsworth Cengage Learning.

Barry, P. (2019). Beginning Theory: An Introduction to Literary and Cultural Theory. Manchester: Manchester University Press.

Christine, C. \& Widyastuti, D. (2017). Mia Hall's Decision-making Process in Her Comatose State in Gayle Forman's If I Stay: A Psychoanalytic Study. Journal of Language Literature 17(1), 49-64.

Cherry, K. (2019). Id, Ego, and Superego Are Part of a Structural Model of Personality. Very Well Mind. Retrieved from https://www.verywellmind.com/the-id-ego-and-superego$\underline{2795951}$

Cherry, K. (2020). The Structure and Levels of the Mind According to Freud. Very Well Mind. Retrieved from https://www.verywellmind.com/the-conscious-and-unconsciousmind-2795946

Conscious vs Unconscious Thought in Making Complicated Decisions. (2008, December 1). Association for Psychological Science. Retrieved from https://www.psychologicalscience.org/news/releases/conscious-vs-unconsciousthought-in-making-complicated-decisions.html

Feist, J. \& Gregory J. F. (2006). Theories of Personality. New York: McGraw-Hill Education. Forman, G. (2010). If I Stay. New York: Speak, Penguin Group.

Hodge, J (2017, December 2). Survival is the Only Moral Goal of Life. The General Science Journal. Retrieved from https://www.gsjournal.net/Science-Journals/EssaysPhilosophy/Download/7112

Hossain, M. Md. (2017). Psychoanalytic Theory Used in English Literature: A Descriptive Study. Global Journal of Human-Social Science: Linguistics \& Education, 17(1), 4046.

Jonassen, D. H. (2012, January 6). Designing for Decision-making. Association for Educational Communications and Technology, 60, 341-359.

Ju U., Kang J. \& Christian W. (2019, February 05). To Brake or Not to Brake? Personality Traits Predict Decision-Making in an Accident Situation. Frontiers in Psychology, 10:134. 
Journal of Literature, Linguistics, and Language Teaching

Volume 2 (2) 2021

ISSN:2746-8968

https://journal.unesa.ac.id/index.php/nld/index

Labaree, R. V. (2019) Organising Your Social Sciences Research Paper: Types of Research Designs. USC Libraries. Retrieved from https://libguides.usc.edu/writingguide/qualitative

Leung, M. (2014, September 16). Watching If I Stay is an Excellent Decision (Review). Young Post. Retrieved from https://www.scmp.com/yp/discover/entertainment/movies/article/3057409/watching-ifi-stay-excellent-decision-review

Margawati, P. (2010). A Freudian Psychological Issue of Women Characters in Daphne Du Maurier's Novel Rebecca. Language Circle Journal of Language and Literature IV.

McLeod, S. A. (2019). Id, Ego and Superego. Simply Psychology. Retrieved from https://www.simplypsychology.org/psyche.html

McLeod, S. A. (2020, March 20). Maslow's Hierarchy of Needs. Simply Psychology. Retrieved from https://www.simplypsychology.org/maslow.html

McTernan, M., Love, P., \& Rettinger, D. (2013). The Influence of Personality on the Decision to Cheat. Ethics \& Behavior, 24(1), 53-72. https://doi.org/10.1080/10508422.2013.819783. Missa, D. Y. (2015, June 18).

Kebutuhan Dasar Anak. Kompasiana. Retrieved from https://www.kompasiana.com/atonimeto/54f690eba3331137028b50c7/kebutuhandasar-anak

Moore, B. D. (2021, March 15). How The Effects of Decision-making Impact Our Lives: 9 Examples. Great Work Life. Retrieved from https://www.greatworklife.com/effects-ofgood-decision-making-examples/

Newell, B. R \& Shanks D. R. (2014). Unconscious Influences on Decision-making: A Critical Review. Behavioral and Brain Sciences, 38(1), 25-97. Retrieved from https://discovery.ucl.ac.uk/id/eprint/1419217/1/Newell_\%26_Shanks_Final_Copyedite d.pdf

Respatio, R. C. (2018, September 01). Applications of Freudian Psychoanalysis in Rebecca. Culturalistics: Journal of Cultural, Literary, and Linguistic Studies, 2(3), 30-38.

Schultz, D. P. \& Sydney E. S. (2017). Theories of Personality (12 ${ }^{\text {th }}$ ed.). Cengage Learning. Shahsavarani, A. M. \& Esfandiar A. M. A. (2015). The Bases, Principles, and Methods of Decision-making: A Review of Literature. International Journal of Medical Reviews.

Strack, F., \& Deutsch, R. (2004, August 1) Reflective and Impulsive Determinants of Social Behavior. Personality and Social Psychology, 8, 220-247.

Vinney, C. (2019, February 28). Freud: Id, Ego, and Superego Explained. ThoughtCo. Retrieved from https://www.thoughtco.com/id-ego-and-superego-4582342 